\title{
FROM PILOT TO SCALE - A FRAMEWORK FOR DEVELOPMENT PRACTITIONERS FOR MARKET DRIVEN VOCATIONAL TRAINING
}

\author{
Jaime Moll de Alba* \\ United Nations Industrial Development Organization (UNIDO), Austria \\ Virpi Stucki \\ United Nations Industrial Development Organization (UNIDO), Austria
}

\begin{abstract}
Partnerships bringing together both the private and the public sector, as well as development actors might play an important role in facilitating the acquisition of skills and thereby support sustainable socioeconomic development, notably in the manufacturing sector. The participation of the private sector in such partnerships contributes to enhance the adequacy between skills supply and demand and thereby spurs employability and economic activity. This paper makes use of the case study method to analyse the role of this kind of partnership in skills acquisition in five industrial development projects in Africa. We hypothesize that the Market System Development (MSD) approach offers potential to enhance the impact of skills acquisition partnerships. We conclude by proposing an innovative framework to support policymakers and development practitioners to conceptualise new skills development partnerships through the application of the MSD approach contributing to systemic change and long-term sustainability.
\end{abstract}

Keywords: Market System Development, Public Private Development Partnership, Industrial Development, Skills Acquisition, Sustainable Development Goals, Fourth Industrial Revolution, COVID-19.

Received: 10 September 2020

Accepted: 10 May 2021

https://doi.org/10.33736/ijbs.3749.2021

\section{INTRODUCTION}

\subsection{Contribution of the paper}

This paper seeks to present and analyse a unique dataset and the experience gained on the public private development partnership approach used by a United Nations specialised agency to facilitate the skills acquisition of future labour force and the provision of qualified workers to the labour market and thereby contribute to the enhancement of the knowledge and normative base on technical and vocational education and training provision with the direct involvement of the private sector.

The paper makes use of five case studies that build upon the experience gained with five public private development partnership projects to support skills development that were implemented

* Corresponding author: UNIDO, Department of Programme and Partnership Coordination, Vienna, Austria; Email: J.Moll-deAlba@unido.org 
between 2012 and 2020 by the United Nations Industrial Development Organization (UNIDO) and different public, private and development partners. The skills targeted by the five case studies were not identical; the projects in Ethiopia, Liberia, Morocco and Zambia focused on heavy duty equipment and commercial vehicle training whereas the focus of the project in South Africa was on forestry skills development.

The common objective of all five case studies was to address the market failure caused by the mismatch between demand and supply of highly skilled labour in the targeted sector. By doing so, the projects aimed at enhancing business and employment opportunities and thereby contributing to poverty reduction. One can conclude that the five case studies contributed to the achievement of the 2030 Sustainable Development Agenda by targeting the Sustainable Development Goals related to education, decent work, industry and global partnerships (SDG 4, 8, 9, and 17).

This paper makes a substantial contribution to existing knowledge on public private development partnerships to facilitate skills acquisition by putting forward a framework for analysis, using the Market System Development (MSD) approach, to increase the sustainability and systemic change of future public private development partnership projects in skills provision. The framework presented in this paper constitutes an original contribution to the state of the art since the MSD approach has not been applied yet in the context of UNIDO's public private development partnership projects.

The research question we address in the paper can be summarised as follows: Can the MSD approach be applied in the context of partnership skills development projects to achieve systemic change and thereby ensuring scaled-up and long-term sustainability?

\subsection{Rationale for partnerships with the private sector for acquisition of industrial skills}

The international community agreed and set up in 2015 a number of very ambitious and farreaching development objectives, which are encapsulated in the 2030 Agenda for Sustainable Development (UNGA, 2015). The latter comprises 17 mutually reinforcing Sustainable Development Goals that constitute a roadmap to achieve a better world by 2030. Four Sustainable Development Goals that focus on how to achieve quality education, sustainable economic growth, inclusive and sustainable industrial development and forging partnerships for sustainable development lie at the core of this paper.

A well-established fact in the literature is that the industrial sector, more precisely, the manufacturing sector, offers increasing returns of scale and underpins economic growth (see, for instance, Kaldor, 1966; 1981). Recent research (UNIDO, 2019a) indicates that in the period 1991-2018 the growth of the manufacturing value added was higher than that of the gross domestic product confirming the continued leading role of manufacturing in economic growth. Moreover, the manufacturing sector continues to show higher productivity than other sectors of the economy (UNIDO, 2020a).

Industrial development can have also significant impact on social progress (UNIDO, 2019b) as the manufacturing sector plays an important role in in terms of employment and education (UNIDO, 2020b). Albaladejo and Weiss (2017) highlight the changing types of skills required depending on the industrial development stage of economies and the need for training methods to 
evolve accordingly. Chang and Andreoni (2020) underscore the importance of integrating learning and production when devising new industrial policies.

A significant investment gap, which was estimated at US\$ 2.5 trillion annually by UNCTAD (2014), remains unfilled to achieve the Sustainable Development Goals. Moreover, the flows of foreign direct investment are expected to drop up to 40\% in 2020 (UNCTAD, 2020) because of the COVID-19 pandemic the world is currently undergoing. In addition, the contribution of the private sector has not reached the necessary levels to supplement public investment to achieve the Sustainable Development Goals and remains low, particularly in Least Developed Countries (Organisation for Economic Cooperation Development (OECD), 2019) and in the education sector (UNCTAD, 2019).

"Alliances and partnerships produce stability when they reflect realities and interests". This quote by an American author Stephen Kinzer (BrainyQuote, n.d.) demonstrates the current industrial skills development landscape in the present Fourth Industrial Revolution (4IR) era. The provision of technical and vocational education and training is the key to country's industrial competitiveness and development and countries need the right set of skills to match jobs with workers. Yet, the situation in many countries reflects a gap as the skills provided do not match the industry employment needs.

For all the above, we have decided to focus our paper on those partnerships that include the participation of the private sector in the acquisition of industrial skills.

Different ways to provide technical and vocational education and training related skills exist. In many occasions (UNESCO, 2007), the private sector plays role in skills development partly due to the market failure of matching the demand and the supply of skilled labour. The provision of technical and vocational education and training services varies greatly between countries. A database of UNESCO-UNEVOC (2019) presents profiles of 31 countries' training systems and reveals the variety across different countries in entry requirements, options for governance and financing, as well as quality controls in place.

Hoyaux (2019) distinguishes between operational and educational public private partnerships. The former means that a public training service involves private sector partners in operating that service, under different forms of legal contracts, with different degrees of responsibility and with transfer of funds to the public sector. An educational public private partnership means that the different partners, public and private, contribute through advisory services on ad hoc basis. Such advisory services include training of trainers, training/learning materials, quality assurance and accreditation, among others.

Another model to deliver skills exist: the public private development partnership. According to the Swedish International Development Agency (2019), this model enhances development impact by using different methods to deliver and financially support public services. The investment, risks, responsibilities and rewards are thus shared among the public, private and development partners. The public private development partnership model falls under the classification of an educational partnership with the following exemptions: i) collaboration is structured (as opposed to ad hoc) and governed by project document and legally binding 
agreement/s, ii) in addition to public and private partners, a development partner is involved (Hoyaux, 2019).

The role and importance of the private sector in the provision of technical and vocational education and training skills is not likely to be less in the current era of 4IR, which requires governments, industries and individuals to rethink fundamentally the content and the delivery of industrial skills. 4IR is commonly characterised as a fusion of technologies that blurs the borders between the biological, digital and physical spheres (Schwab \& Davis, 2018). Quality skills provision is a key driver of economic growth, as it trains workers for technical and skilled jobs. Yet, currently, many technical and vocational education and training institutions, especially in low-income countries, are unable to adapt their training to the needs of the 4IR partly due to the fact that the private sector, forerunner of 4IR (WEF, 2018), is not sufficiently involved in developing and/or updating the training curricula (The World Bank, 2019).

Previous research suggested the benefits of the partnership approach to acquire skills in developing countries by involving the private sector (Moll de Alba \& Stucki, 2019). Yet, some past evaluation and lessons-learnt studies (UNIDO, 2016; 2017a; 2018a) on the public private development partnership model in skills development have identified challenges in reaching systemic change and ensuring the long-term sustainability of the technical and vocational education and training sector.

Market System Development (MSD) approach address the underlying causes of poor performance in specific markets that matter to people living in poverty, in order to create lasting changes that have a large-scale impact (The Springfield Centre, 2015). The MSD approach stimulates systemic change by shifting the underlying conditions that are holding a complex problem in place. An example of such a problem is the mismatch between supply and demand for industrial skills.

This paper puts forward a framework for analysis of skills development initiatives. The framework builds on existing evidence from partnership projects in skills development, falling under the Learning and Knowledge Development Facility, which is a unique facility focusing on evidence based learning on demand driven skills development, Currently, the facility comprises 12 ongoing public private development partnership projects across ten countries.

Our hypothesis is that the MSD approach can be used in combination with the public private development partnership model in technical and vocational education and training and thereby enhances its impact.

\subsection{Definition of Market System Development approach}

The former UN Secretary General, Kofi Annan, states: "It is the absence of broad-based business activity, not its presence, which condemns much of humanity to suffering. Indeed, what is utopian is the notion that poverty can be overcome without the active engagement of business" (Annan, 2005). According to BEAM Exchange (2020a), supporters of market systems approaches believe that the best way to help people out of poverty is to address the underlying causes of market failure. Rather than focus broadly on macro-economic problems or individually on specific businesses or families, they instead look at the ways poor people and businesses 
interact in particular sectors. By analysing and understanding this, they can help make systemic changes that create lasting, inclusive growth.

The rationale to apply the market systems approach in development cooperation is threefold; (1) to stimulate systemic change, (2) to achieve large scale impact, and (3) to ensure sustainability of development interventions. (ibid)

As stated, the MSD approach stimulates systemic change by shifting the underlying conditions that are holding a complex problem in place such as the mismatch between supply and demand for industrial skills. When the underlying conditions have widespread influence, and are binding constraints, then permanently shifting them is likely to lead to widespread impact on a large scale. The systemic change and the widespread impact ensure that the intervention is sustainable beyond the duration of the intervention. Hence, scale and sustainability are results of systemic change. (BEAM Exchange, 2020b)

According to the Springfield Centre (2015), systemic change is achieved by examining the specific and unique underlying causes of poor performance in particular industries or sub-sectors. Once the underlying causes are analysed, the intervention is designed in a way that stimulates changes in the rules, relationships, barriers and incentives that affect how public and private actors behave, helping important market functions to perform more effectively. The ultimate goals are to improve the whole market system and to enable multiple businesses to innovate, grow, reach out and serve wider populations.

Sustainability is achieved by aligning the objectives of a development intervention with the private incentives and capabilities of key actors in the system. Yet, there are many factors that are outside the control of individual firms or actors, such as social norms, government policies or industry-wide practices. This requires careful analysis of key market functions and players, and how they could work more effectively in the future to overcome the conditions that are holding the problem in the market system in place.

\section{METHODOLOGY}

Yin (2019) defines a case study as "an empirical inquiry that investigates a contemporary phenomenon in depth and within its real-world context". After careful consideration, we decide that cases studies offer the most appropriate approach to test our research hypothesis about the potential offered by MSD approach to enhance the impact of public private development partnership to support skills acquisition in the industrial sector.

UNIDO has accumulated unique experience using the above partnership approach in a number of projects in different industrial subsectors in several developing countries. Supported by UNIDO and the Swedish International Development Agency, the Learning and Knowledge Development Facility provides policymakers and development practitioners with a platform to share and discuss practices and experience in the area of industrial skills development. The facility has developed and promoted a common framework, on the one hand, to facilitate the acquisition of the skills required by the industrial sector and thereby enhance employability and reduce poverty and, on the other hand to meet the labour market demands of skilled labour and thereby underpin 
economic growth. Partnerships, and namely the public private development partnership approach, lie at the core of the facility. The role of the private sector in such partnership projects is fundamental to identify and facilitate the acquisition of skills required by a given industrial subsector as well as the mastering of the key technologies and knowledge the labour should become conversant.

The platform provides information and data on 12 partnership projects in eight countries, namely in Ethiopia (two projects), Iraq, Liberia (two projects), Morocco (three projects), South Africa, Uganda, Uruguay and Zambia. Moreover, the facility partnership projects cover a wide range of industrial subsectors from agro-industry automation in Uruguay to water management in Morocco.

The facility has put over the years emphasis on the development of knowledge products that enhance the impact of such partnership projects. Particular attention has been placed on the collection of data that enables assessing the impact of such projects. For that purpose, the facility stocks information and data of the students who have participated in such project. This database build upon the results of baseline and end line questionnaires on both household and employment status. Standard questionnaires have been developed, tested and used to collect information at the beginning of the training courses with 27 queries whereas end questionnaires, including 17 interrogations, are filled out between 1 to 9 months (depending on the project) after the completion of the training.

For the sake of comparability, we have decided to focus this paper on five industrial sector partnership projects in Africa for which data availability allows an in-depth analysis of the project results. This paper undertakes case studies covering projects in five African countries, namely Ethiopia, Liberia, Morocco South Africa and Zambia. The years covered by the above projects are different and range from 2012 to 2018. The selected five projects are diverse in terms of the partners involved, the national characteristics in which they operate, the admission requirements, and the underlying technical and vocational education and training systems and thereby offers a set of case studies that will allow to draw conclusions beyond the five projects covered by this paper.

\section{RESULTS AND DISCUSSION}

In this section, we present our five case studies. All case studies are public-private partnership skills acquisition projects developed under the umbrella of UNIDO's Learning and Knowledge Development Facility using the same methodological approach thereby enabling the comparison of the results achieved. We first present the specific conditions and features of each case study and then summarise their contribution to systemic change, large-scale impact and sustainability.

The main rationale behind the selection of the five case studies was the availability of both baseline and end line data. The Learning and Knowledge Development Facility focuses on least developed countries explains why all five case studies are located in Africa. The duration of the five case studies ranged from four to six years. Focusing on one continent allowed us to identify similarities and differences stemming from the specific contexts and conditions of the various countries covered by the five case studies. We provide for each case study a succinct description 
of the partnership, as well as selected results based on our analysis of the data contained in the Learning and Knowledge Development Facility database, which summarises the results of the project baseline and end line questionnaires. More information in each partnership project is available on the facility webpage at https://kdfacility.org/

We supplement the above information and data on each project by undertaking a qualitative review of the technical and vocational education and training policies of the respective countries where the projects are hosted. UNESCO-UNEVOC (2019) defines such policies as a "collection of laws and rules that govern the operation of technical and vocational education and training systems". This definition describes well the situation of public private development partnerships in technical and vocational education and training where, in addition to traditional actors, the private and development sectors are contributing to the provision of industrial skills.

The UNESCO-UNEVOC (2019) World technical and vocational education and training database aims at providing concise, reliable and up-to-date information on such training systems worldwide. The database, which is the result of a collaboration between UNESCO-UNEVOC and the technical and vocational education and training stakeholders in each country, contains currently 31 country profiles, particularly the UNEVOC Network Members. The UNEVOC International Centre for Technical and Vocational Education and Training compiles the country profiles and a relevant stakeholder of the respective country validates them.

We analyse the relevant technical and vocational education and training policies for our case study in terms of private sector prevalence using the UNESCO-UNEVOC database for Morocco, South Africa and Zambia, and literature from the Ministry of Education Ethiopia (2008) and Ministry of Education Liberia (2015) for Ethiopia and Liberia, respectively.

\subsection{Case study 1: Ethiopia}

Back in 2012, with financial support of the Swedish International Development Agency, the project upgraded and refurbished the Selam Technical and Vocational College in Addis Ababa to create a pioneering academy in the country focusing on heavy-duty equipment as well as commercial vehicles.

The project has been instrumental to deliver 36-month training courses to an intake of students ranging from 25 to 40 per year. The course content was developed with support from Volvo Group. The approach used in the training courses was very innovative for the country. Its uniqueness is explained by the combination of theoretical and hands-on training. The latter was delivered with the support of state-of-the-art equipment used in industry. Moreover, not only did the training courses included technical training but also focused on the acquisition of soft skills and English language. The project pioneered a new approach in the country to address the high unemployment among the youth, their low levels of educational attainment and the lack of qualified labour demanded by the construction and commercial vehicles maintenance sectors. The project developed a pilot model that has been replicated to other trades in the country, for example driver training (UNIDO, 2019c).

We undertake an analysis of the project data for the years 2012, 2013 and 2014. It is worth mentioning the significant increase in the percentage of females, a proxy of the contribution of 
the project to inclusiveness, from $3.8 \%$ in 2012 to $57.6 \%$ in 2014 . A bit less than two thirds of the trainees claimed to have found a full-time job after the trainings of 2013 and 2014 and all indicated their income had increased in the groups of 2012 and 2014. Finally, in 2014 all trainees were satisfied with the training received.

Ethiopia's National Strategy from 2008 sets the vision, objectives and guiding principles for the country's technical and vocational education and training sector. The chapter on conceptual principles mentions explicitly public-private partnerships. The involvement of the private sector is mentioned in various occasions in the paper; in strengthening institutions, as training providers, in relation to the governance structure and the National technical and vocational education and training Council, as a way to improve the quality and the relevance of training, and finally, in the context of private investment into training.

\subsection{Case study 2: South Africa}

The Government of Finland offered financial support to overcome the challenges faced by the forest sector of South Africa related to the use of new technologies and changes undergone by this sector. During the years 2016-2017 the project trained 218 students in wood drying and kiln building, sawmilling, brush saw operations, saw log optimization, waste-to-energy, and woodworking, as well as on entrepreneurship course. The training courses were as short as five days to reach a maximum duration of 40 days depending on the topics covered.

When looking at the project data for 2016 and 2017, one can notice a high participation of females with almost $58 \%$ in 2017. Due to the nature of this sector, one can appreciate that in 2017 the contribution of the project to job creation was distributed almost equally between employed (42.2\%) and self-employed (42.1\%) and more than half $(55.3 \%)$ increased their revenues after the training resulting in all students recommending such training courses.

The country profile of South Africa is from 2014 and the validation of the profile is conducted by JET Education Services (JET). JET is an independent, non-profit organisation that works with government, the private sector, international development agencies and education institutions to improve the quality of education and the relationship between education, skills development and the world of work (JET Education Services, 2020).

The education strategy of South Africa is governed by the Medium Term Strategic Framework (MTSF), the National Industrial Policy Framework (NIPF) and the Industrial Policy Action Plans (IPAP). Furthermore, the most updated skill needs are developed and assessed by the Ministry of Higher Education and Training (MHET) and published in the National Skills Development Strategy (NSDS) (UNESCO-UNEVOC, 2014).

The most recent NSDS was approved by the MHET in 2018 and is being presented for the National Skills Authority and key stakeholders for their final consideration (Department of Higher Education and Training, Republic of South Africa, 2018) and hence not yet available for analysis. The most recent policy document available for analysis, The White Paper for PostSchool Education and Training (Department of Higher Education and Training, Republic of South Africa, 2014), recognizes the role of the private sector in demand driven, quality technical and vocational education and training. 


\subsection{Case study 3: Liberia}

The Government of Japan supported financially during the period 2013-2018 a project that contributed to Liberia's reconstruction following the civil wars and the Ebola. The project delivered technical and vocational training to underpin economic growth in several key domestic sectors including, among others, mining and construction. The participation of the private operator, Komatsu Ltd, contributed to strengthening a local vocational training centre in Kakata, Margibi county of Liberia. Our data is from year 2016, during which 37 students were trained for periods of two weeks on all aspects relevant to excavator operators. Our dataset is incomplete due to the Ebola outbreak affecting the country during the implementation period.

Female participation in 2016 reached only $2.7 \%$ but is expected to play a catalytic role and contribute to raise the attractiveness of such trainings for women. Almost half of the trainees managed to find a job or become self-employed after the completion of the training. The challenging conditions of the country labour market might explain why $51.6 \%$ of the trainees could not find a job even if the large majority $(94.6 \%)$ of the trainees recommended the raining to others.

Liberia's National policy 2015-2020 and the accompanying operational plan aims to provide a roadmap for a co-ordinated and quality technical and vocational education and training delivery in the country. The policy relies on the country's long-term development objectives, as spelled out in the document "Liberia Rising: Vision 2030".

The policy lists as one of the flaws of the Liberian system the weak linkages between the formal technical and vocational education and training system and the world of work and that the training delivery system has remained largely supply-driven and not demand-driven or aligned to the needs of the employment sector. It lists "partnership with the industry" as one of the key strategies in providing quality and relevant training for all.

The Policy refers to the private sector in three occasions: i) private sector being one of the main training provider in the country, ii) in relation to ICT skills (private sector businesses are viewed as one vehicle to deliver the requisite ICT competencies), and iii) regarding funding of the sector (voluntary contributions, levy and donations) (Ministry of Education Liberia, 2015).

\subsection{Case study 4: Morocco}

In 2015, with financial support from USAID and other partners including the Volvo Group, the project in Morocco established an academy on heavy-duty equipment as well as commercial vehicles. The new academy was integrated into the existing School of building and public works of Settat.

Since its inception, the Academy has trained yearly 150 Moroccan, Senegalese and Ivorian youth in heavy-duty equipment maintenance during nine months long courses. The project had the dual objective to promote youth employability and to stimulate economic and social development in the aforementioned three countries. 
The participation of female reached $6.6 \%$ in the second batch of the 2017 training. Interestingly, the contribution of the project to job creation was exclusively on full-time employment (76.8\%) and more than half of the trainees $(53.7 \%)$ earnt more after having completed the training. Unsurprisingly, all trainees claimed to be satisfied with the training received.

The country profile of Morocco is from 2015 and the College of Technical Education of Mohammed V Souissi University (ENSET) has validated it.

Morocco's technical and vocational education and training policy is governed by the National Strategy for Vocational Training for the period 2015-2021, and the Vocational Training Vision 2020 (UNESCO-UNEVOC, 2015). These strategic documents call for strengthened cooperation with chambers of commerce, businesses and professional associations. Furthermore, in the Royal Speech on the $65^{\text {th }}$ Anniversary of the Revolution of the King and the People, the King called for a "thorough review of vocational training programs to align them with the needs of businesses and the public sector, and to make sure they are adapted to changes in industry and trades in general, thereby increasing the chances of graduates to access professional life" (Kingdom of Morocco, 2018).

\subsection{Case study 5: Zambia}

The project established in 2015, with financial support from the Swedish International Development Agency and the Volvo Group, a centre in Zambia for the operation and maintenance of heavy equipment used in the mining industry, i.e., earthmoving equipment and trucks. The centre was integrated into the existing technical and vocational education program of the Northern Technical College, a public vocational training centre that is located in Ndola and provides training programs in electrical, mechanical, automotive engineering and the applied sciences.

The dataset is from years 2017 and 2018, during which the project trained 156 students on heavyduty equipment maintenance during courses of 15 months duration.

The number of females attracted reached $15.79 \%$ in 2018. More than one third of the students $(37.83 \%)$ managed to find an employment while $54.05 \%$ were unemployed after the training finalised. Half of the trainees maintained or increased their revenues after the training and all were satisfied with its contents.

The country profile of Zambia is from 2010 and the Ministry of Science, Technology and Vocational Training (MSTVT) has validated it.

Zambia's training provision is governed by the $7^{\text {th }}$ National Development Plan including its Implementation Plan, the technical and vocational education and training Policy from 1996 as well as the Vision 2030 document. Both the Policy and the Vision document stresses the importance of technical and vocational education and training in economic development (UNESCO-UNEVOC, 2010). The $7^{\text {th }}$ National Development Plan calls for a fundamental mindset change and creation of "an environment that fosters strong private sector participation in the socio-economic development process". The $7^{\text {th }}$ National Development Plan further calls for private sector engagement across sectors and for economic diversification. In relation to skills, 
the Plan recognizes that "private education and training providers will continue to be important partners in the delivery of education and training for all at all levels". Furthermore, the Plan mentions that curricula will be revised continuously to reflect the global market skills needs.

\subsection{Quantitative findings}

We can see diverse quantitative results achieved by the five case studies in terms of contribution to job creation and earnings, employment situation and student satisfaction. Figure 1 presents the number of students whose earnings decreased, remained the same or increased after having completed the training courses as compared to the baseline situation before the training intervention. Figure 2 presents how students would describe their job situation before and after the training. Figure 3 reveals student satisfaction with the training provided. The diverse contexts in which the projects were launched and implemented might explain, at least partly, such differences.

Figure 1: Earnings of students after completion of training courses in comparison to the situation before the training module (number of students per category). The question asked was "Do you now earn more than before the training?"

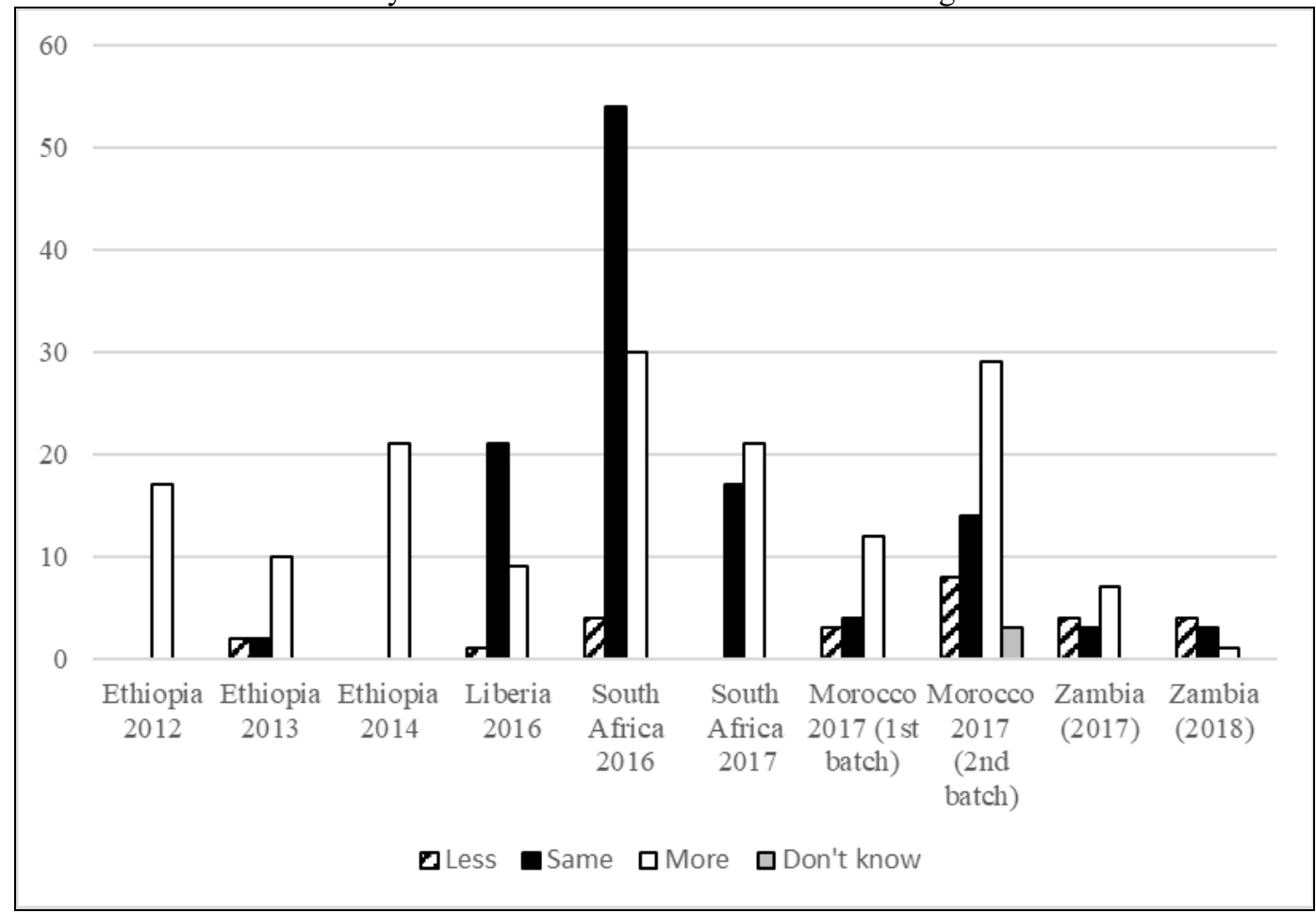

Source: Based on data from the baselines and end lines of the case studies

Figure 2: Job situation after completion of training course in comparison to the situation before the training (number of students per category). The question asked was:

"How would you describe your job situation?" 


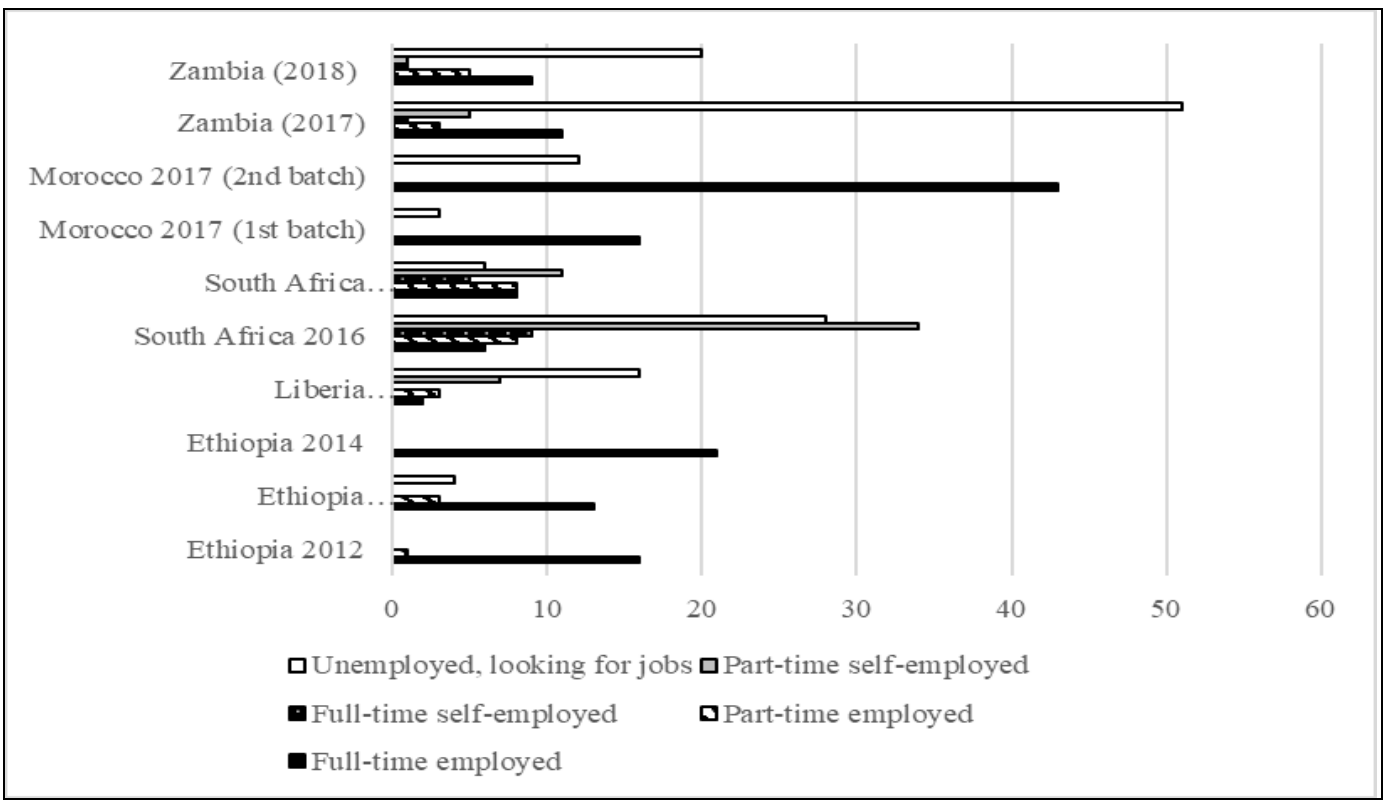

Source: Based on data from the baselines and end lines of the case studies

Figure 3: Student satisfaction after completion of training course in comparison to the situation before the training (number of students per category). The question asked was:

"Would you recommend the course you did at the VTC to your friends and family?"

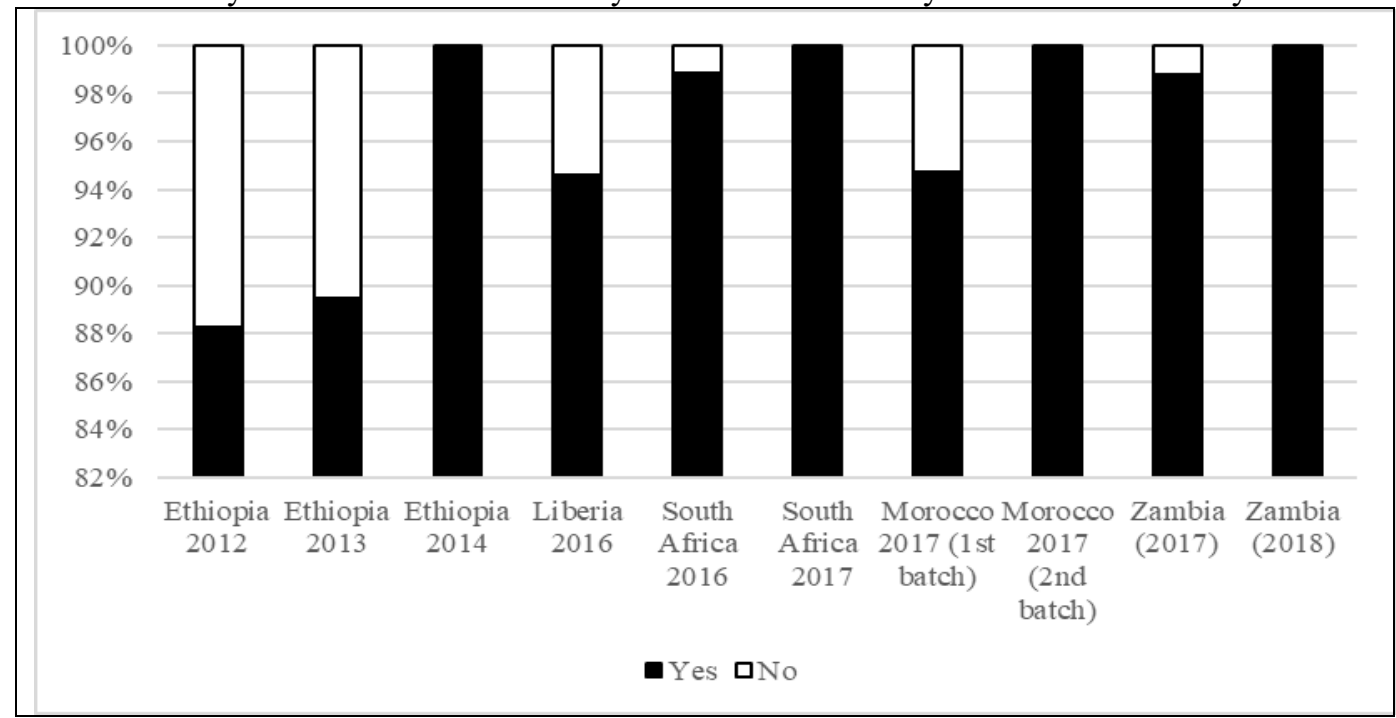

Source: Based on data from the baselines and end lines of the case studies

\subsection{Qualitative findings: contribution to systemic change, large scale impact and sustainability}


The table below summarises the case studies regarding their contribution to systemic change, large-scale impact and sustainability drawing on relevant available documentation, namely independent evaluations, publications on lessons learnt, and project final reports.

\begin{tabular}{|c|c|c|c|}
\hline Project & Systemic change & Large scale impact & "Sustainability \\
\hline $\begin{array}{l}\text { Ethiopia. } \\
\text { Source: } \\
\text { UNIDO } \\
\text { (2018a) }\end{array}$ & $\begin{array}{l}\text { Systemic change was } \\
\text { assessed as partially met. } \\
\text { The choice of the } \\
\text { institution where the } \\
\text { training programme was } \\
\text { set-up (an NGO instead of } \\
\text { a pubic TVET school) was } \\
\text { claimed to partially } \\
\text { influence this. }\end{array}$ & $\begin{array}{l}\text { The project should have } \\
\text { had a greater pro-business } \\
\text { and private sector } \\
\text { engagement to reach } \\
\text { large-scale impact. }\end{array}$ & $\begin{array}{l}\text { The project generated a } \\
\text { business plan including } \\
\text { innovative ways to cover } \\
\text { expenses once the } \\
\text { partnership project ended. } \\
\text { This was assessed as a good } \\
\text { example with a potential for } \\
\text { replication. }\end{array}$ \\
\hline $\begin{array}{l}\text { South Africa. } \\
\text { Source: } \\
\text { UNIDO } \\
(2017 b)\end{array}$ & $\begin{array}{l}\text { Systemic change in the } \\
\text { national vocation training } \\
\text { policies was assessed } \\
\text { unlikely due to the limited } \\
\text { involvement in discussions } \\
\text { about national curricula } \\
\text { changes, national trainer } \\
\text { training, policy changes or } \\
\text { institutional development. }\end{array}$ & $\begin{array}{l}\text { Limited impact due to the } \\
\text { same reasons as listed } \\
\text { under "systemic change". }\end{array}$ & $\begin{array}{l}\text { Financial, technical and } \\
\text { organizational sustainability } \\
\text { were assessed as moderately } \\
\text { likely indicating that the } \\
\text { project had succeeded in } \\
\text { designing and implementing } \\
\text { the project activities in a } \\
\text { sustainable manner. }\end{array}$ \\
\hline $\begin{array}{l}\text { Liberia. } \\
\text { Source: } \\
\text { UNIDO } \\
(\mathbf{2 0 1 8 b})\end{array}$ & $\begin{array}{l}\text { The project was stated to } \\
\text { have contribution to system } \\
\text { change regarding gender } \\
\text { participation to a } \\
\text { traditionally male- } \\
\text { dominated field. }\end{array}$ & $\begin{array}{l}\text { The training programme } \\
\text { set-up by the project was } \\
\text { assessed viable in the } \\
\text { short-term. The long-term } \\
\text { impact was assessed to } \\
\text { depend on many external } \\
\text { factors, including } \\
\text { availability of human and } \\
\text { financial resources, TVET } \\
\text { sector governance in the } \\
\text { country and the contact to } \\
\text { the private sector. }\end{array}$ & $\begin{array}{l}\text { For long-term sustainability, } \\
\text { the project would need to } \\
\text { proactively manage and } \\
\text { market the training } \\
\text { programme as well as } \\
\text { strengthen linkages with the } \\
\text { relevant ministries and the } \\
\text { private sector. }\end{array}$ \\
\hline $\begin{array}{l}\text { Morocco. } \\
\text { Source: } \\
\text { UNIDO } \\
(2020 c)\end{array}$ & $\begin{array}{l}\text { The independent evaluation } \\
\text { concluded that "system } \\
\text { transformations take time } \\
\text { and rarely do they take } \\
\text { place within the time span } \\
\text { of the intervention". } \\
\text { Therefore, the evaluation } \\
\text { did not address the } \\
\text { project's contribution to } \\
\text { system change. }\end{array}$ & $\begin{array}{l}\text { The project impact was } \\
\text { assessed as successful } \\
\text { pilot, which established } \\
\text { good practices for } \\
\text { demand-driven skills } \\
\text { development. }\end{array}$ & $\begin{array}{l}\text { The technical, governance } \\
\text { and financial sustainability } \\
\text { were assessed as } \\
\text { satisfactory; the lack of } \\
\text { sustainability/exit strategy } \\
\text { being mentioned as main } \\
\text { shortcomings. }\end{array}$ \\
\hline $\begin{array}{l}\text { Zambia. } \\
\text { Source: }\end{array}$ & $\begin{array}{l}\text { The final report noted that } \\
\text { the project set-up benefitted }\end{array}$ & $\begin{array}{l}\mathrm{n} / \mathrm{a} \text { in the project final } \\
\text { report. }\end{array}$ & $\begin{array}{l}\text { According to the final } \\
\text { project report, careful }\end{array}$ \\
\hline
\end{tabular}




$\begin{array}{lll}\text { UNIDO } & \text { from the lessons-learnt of } \\ \text { (2019d) } & \begin{array}{l}\text { efforts are needed to } \\ \text { projects under the Learning } \\ \text { and Knowledge }\end{array} & \begin{array}{l}\text { maintain the technical, } \\ \text { financial and organizational } \\ \text { Development Facility by } \\ \text { establishing the new } \\ \text { training programme within } \\ \text { existing TVET structures. }\end{array} \\ \end{array}$

\subsection{Discussion and proposal for development practitioners of Market System Development approach}

To systematise the positive results emerging from the projects, we propose to thoroughly analyse the underlying conditions and contexts in which the particular partnership project is set up. In view of the above, in this section we introduce an innovative proposal to make use of the MSD approach to cater for the specific conditions of new partnership projects and thereby enhance systemic change ultimately leading to scaling up and sustainability.

It should be noted that the MSD approach was not used in the cases presented in this paper. The MSD is proposed as a framework to methodise the positive, yet uneven, outcomes of the public private development partnership projects. The approach will be tested for the first time ever in a recently launched project Design of a public private development partnership between Sida, Volvo and UNIDO in the Democratic Republic of the Congo, using the market system development approach (UNIDO, 2020d). More information about the suitability of MSD in the context of skills provision using the public private development partnership project approach will become available after the project completion and could be used in future research.

As the case studies revealed, the results and impact of the individual partnership project vary between industrial sectors, countries and even between the years in the same country. To systematise the positive results of public private development partnership projects to and their impact in terms of employment creation and earnings, female participation in industrial sectors traditionally reserved to men, the underlying conditions in the technical and vocational education and training system should be analysed. For this, we propose the following framework analysis in applying MSD for public private development partnerships.

The challenge in combining the MSD approach and partnership project stems from the sequence in which the system is analysed. In a conventional MSD approach, the Diagnostic process starts by analysing the market and identifying suitable interventions (see Figure 2). The LKD facility has shown (UNIDO, 2016; 2017a; 2018a) that the public private development partnership approach produces quality education and therefore contributes to filling the skills gap, and ultimately to economic growth. For example, an analysis of a project in Ethiopia concluded that involving the private sector actively as a full partner raises the quality and relevance of training, which is essential for creating job opportunities and reducing skills and productivity gaps in the private sector (UNIDO, 2018a).

Figure 2: Diagnostic process of MSD approach 


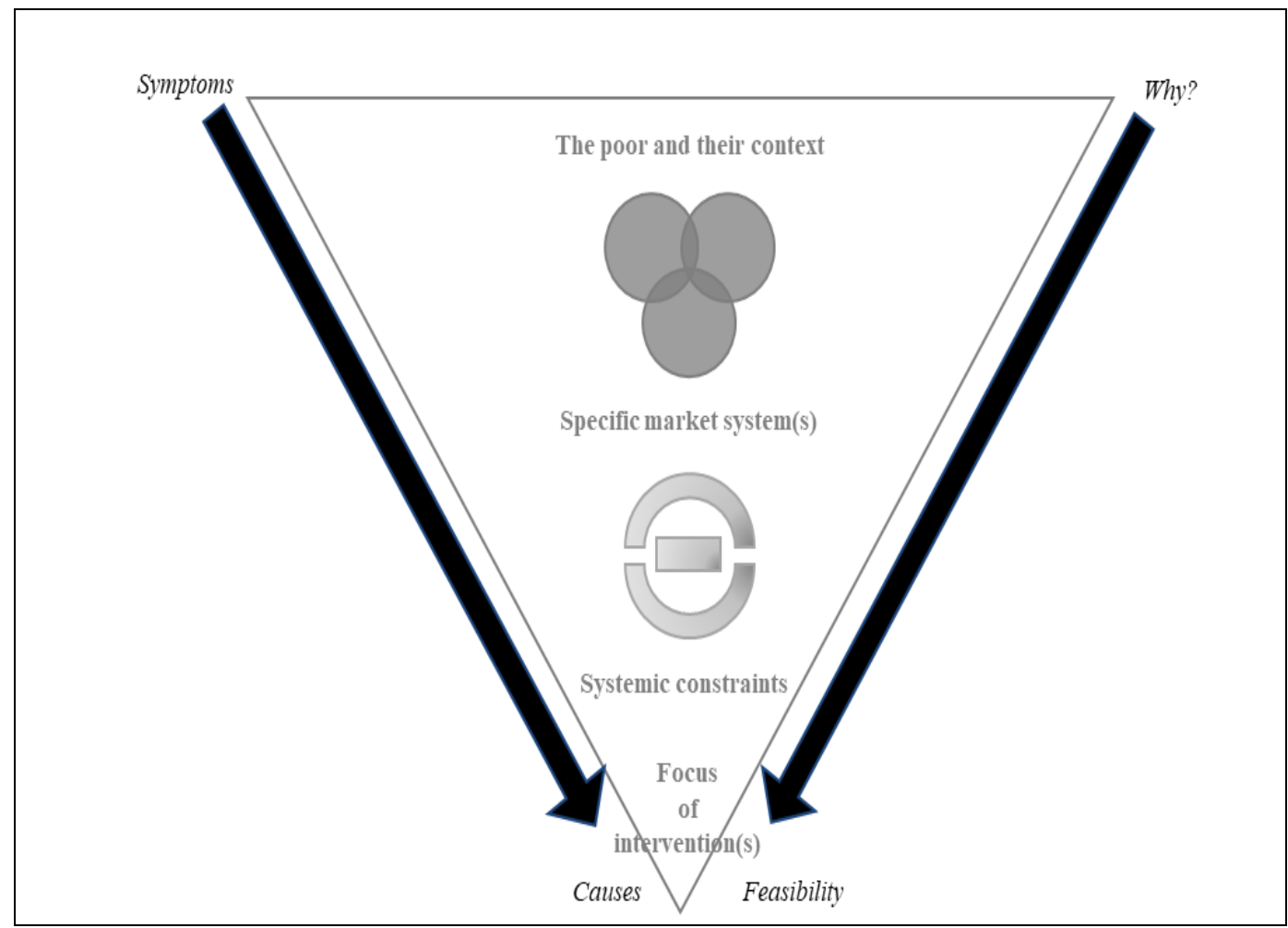

Source: Modified from the Springfield Centre (2015)

Yet, the partnership interventions would have benefitted by addressing i) all the critical constraints of the market failure (the mismatch between the demand and supply of skills) and ii) identifying opportunities to change the important conditions behind this mismatch. Furthermore, whereas some of the critical constraints for the mismatch are common in the skills sector, country and sectoral variations exist and should be analysed separately in each intervention. All the above are part of the MSD Diagnostic process (the Springfield Centre, 2015). As stated in the analysis of the partnership project in Ethiopia: "Context matters" (UNIDO, 2018a). Such partnership projects are likely to succeed better in high growth environments, such as Ethiopia, where the demand for qualified workers remains constantly high and employment outcomes are hence positive, and where there are strong incentives for private sector and the broader government, beyond the Ministries of Education and Training, to continue supporting the model. The study continues, "there is a need to strengthen business engagement, starting off by mapping out the most important and strategically important actors".

Mapping the most important players and identifying the opportunities to change the important conditions in the system are the two topics where the MSD approach can help in developing the new partnership projects.

We suggest that the Learning and Knowledge Development Facility, and other technical and vocational education and training models in collaboration with the private sector, should continue 
developing and implementing skills development using the public private development partnership model (the intervention). The MSD approach should be used to analyse systemic constraints, the broad market system and to identify the beneficiary context in order to maximize the scale change and long-term sustainability in a partnership intervention, hence shifting the underlying conditions of the system. This would imply using the Diagnostic process of the MSD approach but taking the market demand identified by the private partner, and hence the partnership project, as a starting point, validating it jointly with the key stakeholders of the system, and building the project intervention logic and implementation strategy in the broader context of the systemic constraints, specific market system, and context (see Figure 3).

Figure 3: Applying the MSD approach for public private development partnership intervention.

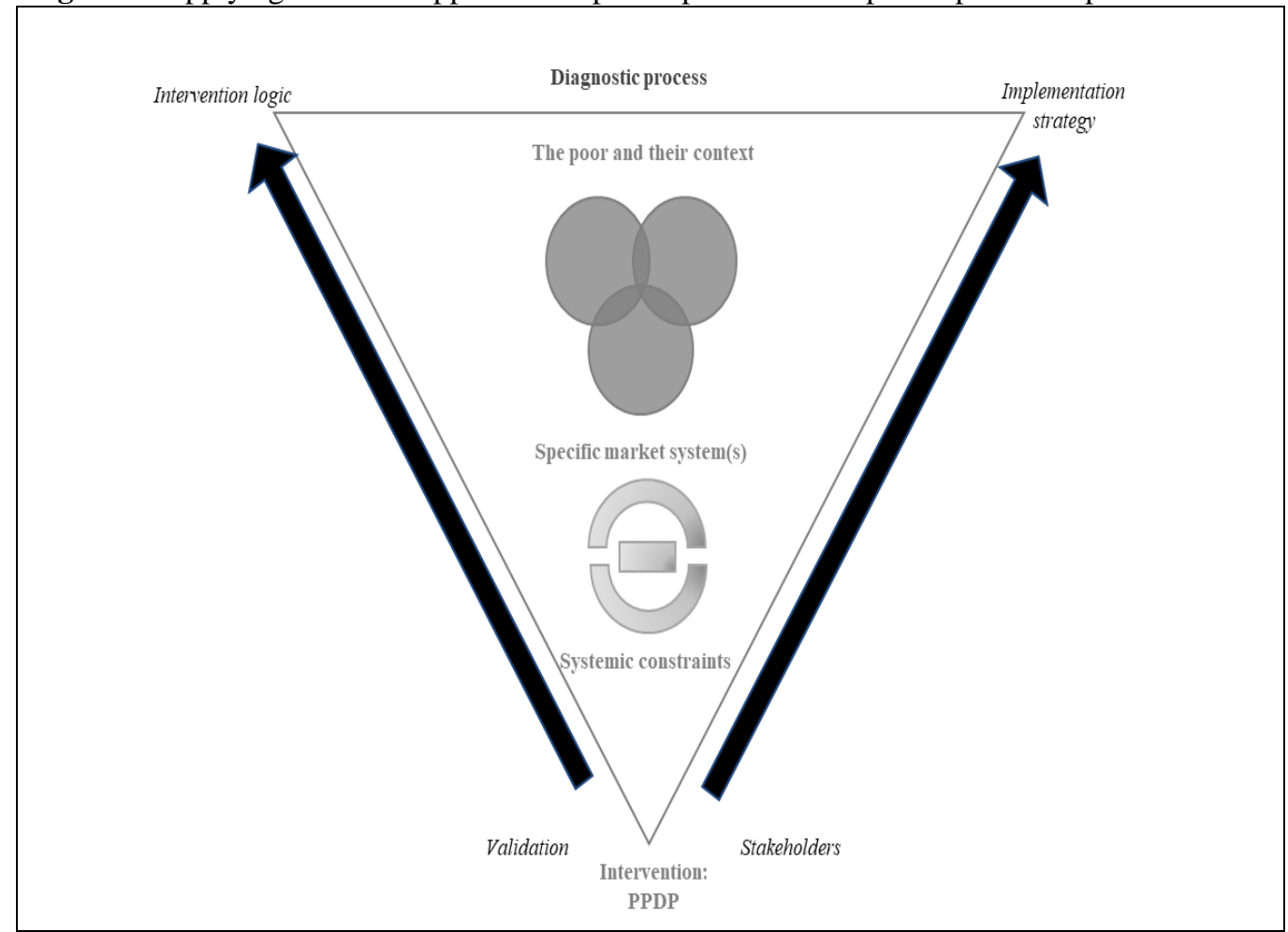

Source: Modified from the Springfield Centre (2015)

\section{CONCLUSION}

Last years have witnessed a general recognition of the role that the manufacturing sector can play to underpin economic growth and development (UNIDO, 2019e; 2020a). The inclusion in the 2030 Sustainable Development Agenda (UNGA, 2015) of an SDG, namely number 9, dedicated to inclusive and sustainable development constitutes a good proof of the increasing attention paid to the leading role played by the industrial sector in driving development. Recent reviews (UN, 
2019) of the progress towards the achievement of SDG 4 on how to achieve quality education, which plays a key role to underpin industrial development, indicate that despite progress "existing skills do not match the jobs of tomorrow and newly acquired skills may quickly become obsolete". The existing gap between the demands of the manufacturing sector for skilled labour seem to be widening even in an industrialised country like the US as pointed out by Deloitte and The Manufacturing Institute (2018) which estimated that as many as 2.4 million positions would remain unfilled between 2018 and 2028 in the US manufacturing sector.

There is also wider recognition that the private sector (UNIDO, 2019e) should take a prominent role to address the challenges posed by the new industrial revolution and the plethora of emerging technologies that are changing the way humankind lives and interacts. Recent studies, see for instance the work of the World Economic Forum (2020), again highlight the importance of soft skills in future jobs. The unprecedented changes our society is facing are illustrated, by instance, by estimates that indicate that more than half of employees will require re- and upskilling (WEF, 2019a), which calls for concerted action from all concerned actors including the private sector to create a long-life learning system that places skills at its core (WEF, 2019b). The concerns raised in recent years by the future of jobs and the impact of the 4IR on employment have been increased by the severe impact on economic activity and foreseen job losses compounded by the COVID-19 pandemic outbreak in 2020. The negative impact in manufacturing activity is particularly severe as illustrated by recent data on the index of industrial production published by UNIDO (2020e). Autor and Reynolds (2020) confirm the challenges derived from the automation for the US labour market and the acceleration of the process by COVID-19 while Barrero et al. (2020c) point out that a significant share of the jobs lost because of COVID-19 in the US will disappear for good.

In this paper, we have reviewed the experience gained by UNIDO making use of the partnership approach to support the acquisition of skills in the industrial sector through partnering with operators of the private sector. We have focused our attention on five partnership projects in Africa, namely in Ethiopia, Liberia, Morocco, South Africa, and Zambia. The five case studies bring together a sample of 458 students for which we have analysed data collected prior and after the completion of the training in terms of inclusiveness (measured by female participation), employability (including self-employment) and increase in income, as well as interest of the training delivered. Our case studies have pointed out that the partnership approach has a positive effect in facilitating the acquisition of skills in industrial sectors.

The results, even if positive, change from one case study to one other. It is important to bear in mind that the national contexts in which the five projects operate are significantly different. In addition, the projects do not cover the same time span and years. Finally, not all five case studies focused on the same industrial sectors and technical disciplines. The above constitutes a limitation and constrains the comparability of our analysis and conclusions. At the same time, it also constitutes a good evidence that despite such differences the partnership approach seems to constitute a suitable mechanism to support the acquisition of skills required by the industrial sector and benefit from its participation in such projects. We have also undertaken a quality review of the technical and vocational education and training policies of the five countries covered by our case studies. It is worth mentioning that the policy documents of all the five countries mentioned the role of the private sector in this field. 
This paper makes a contribution to the existing body of knowledge by introducing a novel approach to make use of the MSD approach to enhance the public private development partnership model in the technical and vocational education and training sector. For that purpose, we have presented a framework for analysis that seeks to increase both sustainability and systemic change. From our analysis, we can derive a set of recommendations to improve the partnership model based on the results of the case studies, notably:

- Partnership project partners should participate in the MSD approach, especially the Diagnostic process to ensure the broad identification of the specific market system constraints from early stages of project development. Key partners should stay engaged during the project implementation to flag out potential new or redundant systemic constraints.

- The public sector should enable the favourable policy environment, such as adoption and accreditation of new curricula, for maximum systemic change and thereby scale and sustainability.

- The private sector should share the necessary information about the market demand to guide the MSD approach Diagnostic process, including the demand for a skilled labour, in specific trade in the short, medium and long term.

- Development partners should allow flexibility required by the MSD approach when designing the intervention logic and implementation strategy and especially when implementing the partnership project. Specific market systems (e.g., changes in global commodity prices for example in the mining sector) and systemic constraints are dynamic rather than static and corresponding flexibility in project duration, Key Performance Indicators, changes to logical framework and even target beneficiaries are most likely required during the project implementation.

In addition, to offer a new approach to policymakers and development partners seeking to enhance the impact of partnership projects in the field of skills acquisition and employability, this paper points out a number of areas that deserve further research. It would be of particular interest to identify a set of partnership projects covering the same set of technical trainings, periods and duration of trainings to be able to derive more accurate conclusions on the impact of such projects. From a research perspective, it would be of great interest to analyse the results of partnership projects that are formulated using the MSD approach and compare the results in terms of inclusiveness, employability and income with partnership projects that do not apply the MSD approach.

\section{ACKNOWLEDGEMENT}

We would like to thank the editor and the anonymous peer-reviewers for their comments and Stefan Windberger for the data compilation. The Swedish International Development Cooperation Agency and UNIDO funded the Learning and Knowledge Development Facility project while the by the Governments of Finland and Japan and the United States Agency for International Development supported financially the PPDP projects.

Disclaimer: The views expressed herein are those of the author(s) and do not necessarily reflect the views of the United Nations Industrial Development Organization. (As provided for in Administrative Circular UNIDO/DA/PS/AC.69 of 17. December 1990). Mention of firm names or commercial products does not constitute an endorsement by UNIDO. 


\section{REFERENCES}

Albaladejo, M., \& Weiss, M. (2017). Skills policy instruments for industrial development in low and middle-income countries. UNIDO Working Paper 2/2017, Vienna.

Annan, K. (2005, June 14). Secretary-General's Address to meeting on "The Business Contribution to the Millennium Development Goals". https://www.un.org/sg/en/content/sg/statement/2005-06-14/secretary-generals-addressmeeting-business-contribution-millennium

Autor, D., \& Reynolds, E. (2020). The Nature of Work after the COVID Crisis: Too Few LowWage Jobs. https://www.brookings.edu/research/the-nature-of-work-after-the-covidcrisis-too-few-low-wage-jobs/

Barrero, J., Bloom, N., \& Davis, S. (2020). COVID-19 Is Also a Reallocation Shock. Cambridge, MA: National Bureau of Economic Research.

BEAM Exchange. (2020a). Why a systems approach?. Retrieved August 12, 2020 from https://beamexchange.org/market-systems/why-use-systems-approach/

BEAM Exchange. (2020b). Features of a market systems approach. Retrieved August 12, 2020, from https://beamexchange.org/market-systems/key-features-market-systems-approach/

BrainyQuote. (n.d.). Stephen Kinzer Quotes. Retrieved July 8, 2020, from https://www.brainyquote.com/quotes/stephen_kinzer_652315

Chang, H-J., \& Andreoni, A. (2020). Industrial Policy in the 21st Century. Development and Change, 51(2), 324-351. https://doi.org/10.1111/dech.12570

Deloitte and The Manufacturing Institute. (2018). Skills gap and the future of work study. Retrieved August 28, 2020, from https://www2.deloitte.com/content/dam/insights/us/ articles/4736_2018-Deloitte-skills-gap-FoW-manufacturing/DI_2018-Deloitte-MFI-skillsgap-FoW-study.pdf

Department of Higher Education and Training, Republic of South Africa. (2018). National Skills Development Plan (NSDP). Presentation to Portfolio Committee of Higher Education and Training. https://slidetodoc.com/department-of-higher-education-and-training-nationalskills-2/

Department of Higher Education and Training, Republic of South Africa. (2014). White Paper for Post-School Education and Training. https://www.che.ac.za/media and publications/legislation/white-paper-post-school-education-and-training

Hoyaux, A. (2019). Development of public private partnerships in technical vocational education and training [Unpublished Document]. Luxembourg Development Cooperation Agency.

JET Education Services. (2020). About: The JET Story. Retrieved July 7, 2020, from https://www.jet.org.za/

Kaldor, N. (1966). Causes of the Slow Rate of Economic Growth of the United Kingdom. Cambridge: Cambridge University Press.

Kaldor, N. (1981). The Role of Increasing Returns, Technical Progress and Cumulative Causation in the Theory of International Trade and Economic Growth. Economie appliquée, 34(4), 593-617. 
Kingdom of Morocco (2018). Full Text of Royal Speech on 65th Anniversary of the Revolution of the King and the People. Retrieved August 14, 2020, from http://www.maroc.ma/en/royal-speeches/full-text-royal-speech-65th-anniversaryrevolution-king-and-people

Ministry of Education (MoE) Ethiopia. (2008). National Technical and Vocational Education and Training (TVET) Strategy (2 ${ }^{\text {nd }}$ ed.). http://www.unesco.org/education/edurights Imedia/docs/c93aa57e340844f8e8e4c3868c68fb3b8054ac61.pdf

Ministry of Education Liberia. (2015). National Policy for Technical and Vocational Education and Training (TVET). Monrovia: Liberia.

Moll de Alba, J., \& Stucki, V. (2019). Enhancing youth employability: a public private development partnership (PPDP) model to acquire industrial skills. International Journal of Economics and Business Research, 17(1), 1-17. https://doi.org/10.1504/IJEBR.2019.10016869

Organisation for Economic Cooperation Development. (OECD) (2019). Blended Finance in the Least Developed Countries 2019. Paris: OECD Publishing. https://doi.org/10.1787/1c142aae-en

Schwab, K., \& Davis, N. (2018). Shaping the Fourth Industrial Revolution. World Economic Forum. https://www.weforum.org/focus/shaping-the-fourth-industrial-revolution

The Springfield Centre. (2015). The operational guide for the making markets work for the poor (M4F) Approach. ( $2^{\text {nd }}$ ed.). http://www.springfieldcentre.com/wp-content/uploads/2015/ 11/2015-09-M4P-Op-Guide-Sept2015.pdf

Swedish International Development Agency. (2019). Collaboration opportunities - Public Private Development Partnership. Retrieved January 4, 2019, from http://www.sida.se/English/partners/our-partners/Private-sector/About-Business-forDevelopment/Public-Private-Development-Partnerships-PPDP/

The World Bank (2019 May, 20-22). Destination digital Africa: preparing our youth for the future. 5th PASET Forum, Event report. Kigali, Rwanda.

UNESCO (2007 May, 23-25). International Consultation on Education for Sustainable Development: Engaging the Corporate Sector. Meeting report. Bonn, Germany.

UNESCO-UNEVOC (2010). World TVET Database - Zambia. Retrieved August 28, 2020, from https://unevoc.unesco.org/wtdb/worldtvetdatabase_zmb_en.pdf

UNESCO-UNEVOC (2014). World TVET Database - South Africa. Retrieved January 4, 2019, from https://unevoc.unesco.org/wtdb/worldtvetdatabase_zaf_en.pdf

UNESCO-UNEVOC (2015). World TVET Database - Morocco. Retrieved January 4, 2019, from https://unevoc.unesco.org/wtdb/worldtvetdatabase_mar_en.pdf

UNESCO-UNEVOC (2019). World TVET Database - Country Profiles. Retrieved July 4, 2020 , from https://unevoc.unesco.org/home/TVET+Country+Profiles

United Nations. (UN) (2019). High Level Political Forum Review of SDG implementation and interrelations among goals Discussion on SDG 4 - Quality education. Background note. Retrieved August 28, 2020, from https://sustainabledevelopment.un.org/content/ documents/23669BN_SDG4.pdf 
United Nation Conference on Trade and Development. (UNCTAD) (2014). World Investment Report, 2014: Investing in the SDGs: An Action Plan. New York and Geneva: United Nations. https://unctad.org/system/files/official-document/wir2014_en.pdf

United Nation Conference on Trade and Development. (UNCTAD) (2019). SDG Investment Trends Monitor. New York and Geneva: United Nations. https://unctad.org/system/files/official-document/diaemisc2019d4_en.pdf

United Nation Conference on Trade and Development. (UNCTAD) (2020). World Investment Report, 2020: International Production: Beyond the Pandemic. New York and Geneva: United Nations. https://unctad.org/system/files/official-document/wir2020_en.pdf

United Nations General Assembly (UNGA) (2015). Resolution Transforming our world: the 2030 Agenda for Sustainable Development, UNGA Resolution 70/1, A/RES/70/1. United Nations, New York. https://www.un.org/en/development/desa/population/migration/ generalassembly/docs/globalcompact/A_RES_70_1_E.pdf

United Nations Industrial Development Organization. (UNIDO) (2016). Swedish Academy for Training. Lessons learnt from a Public Private Development Partnership. Learning and Knowledge Development Facility. https://lkdfacility.org/resources/sat-lessons-learntfrom-a-public-private-development-partnership/

United Nations Industrial Development Organization. (UNIDO) (2017a). Académie Engins Lourds et Véhicules Commerciaux (AGEVEC). Lessons learnt from a Public Private Development Partnership. Learning and Knowledge Development Facility. https://lkdfacility.org/resources/agevec-lessons-learnt-from-a-public-private-developmentpartnership/

United Nations Industrial Development Organization. (UNIDO) (2017b). Independent Final Evaluation. Revitalization of Forest Training Centers in the SADC Region for Green Employment (Phase I and Phase II). UNIDO: Vienna, Austria: UNIDO. https://www.unido.org/sites/default/files/2017-07/RAF-130067_SADC-Forest_Eval Report_FINAL 0.pdf

United Nations Industrial Development Organization. (UNIDO) (2018a). Heavy Duty Equipment and Commercial Vehicles Academy (HDECoVA). Lessons learnt from a Public Private Development Partnership, Vienna, Austria: UNIDO. https://lkdfacility.org/resources/heavy-duty-equipment-and-commercial-vehiclesacademy-hdecova-lessons-learned-from-a-public-private-development-partnership/

United Nations Industrial Development Organization. (UNIDO) (2018b). Lessons-learnt: Promoting Youth Employment by supporting Technical and Vocational Training in Liberia. Vienna, Austria: UNIDO.

United Nations Industrial Development Organization. (UNIDO) (2019a). Industrial Development Report 2020. Industrializing in the digital age, Vienna, Austria: UNIDO. https://www.unido.org/sites/default/files/files/2019-12/UNIDO\%20IDR20\%20main\%20 report.pdf

United Nations Industrial Development Organization. (UNIDO) (2019b). Competitive Industrial Performance Report 2018, Biennial CIP report, edition 2018, Vienna, Austria: UNIDO. https://www.unido.org/sites/default/files/files/2019-05/CIP.pdf 
United Nations Industrial Development Organization. (UNIDO) (2019c). Creating Opportunities through Vocational Training. Results of a Baseline Survey among Commercial Vehicle Drivers in Addis Ababa, Ethiopia. UNIDO: Vienna, Austria: UNIDO. https://open.unido.org/api/documents/14158583/download/Creating\%20Opportunities\%2 0Through\%20Vocational\%20Training Misale\%20Baseline\%20Report.pdf

United Nations Industrial Development Organization. (UNIDO) (2019d). 18th General Conference Abu Dhabi Declaration, Abu Dhabi. https://www.unido.org/sites /default/files/files/2019-11/UNIDO_Abu_Dhabi_Declaration.pdf

United Nations Industrial Development Organization. (UNIDO) (2020a). Industrialization as the driver of sustained prosperity. Vienna, Austria: UNIDO. https://www.unido.org/sites/default/files/files/2020-04/UNIDO_Industrialization_Book_ web4.pdf

United Nations Industrial Development Organization. (UNIDO) (2020b). How industrial development matters to the well-being of the population: Some statistical evidence. Vienna, Austria: UNIDO. https://www.unido.org/sites/default/files/files/202002/HOW\%20INDUSTRIAL\%20DEVELOPMENT\%20MATTERS\%20TO\%20THE\%20 WELL-BEING\%20OF\%20THE\%20POPULATION\%20FIN.pdf

United Nations Industrial Development Organization (UNIDO) (2020c). Design of a public private development partnership between Sida, Volvo and UNIDO in the Democratic Republic of the Congo, using the market system development approach. Project Document. Vienna, Austria: UNIDO. https://open.unido.org/api/documents/19730728/download /190404\%20Prodoc\%20(annexed\%20to\%20signed\%20agrrement).pdf

United Nations Industrial Development Organization. (UNIDO) (2020d). Independent Terminal Evaluation - Morocco, Training Academy for Heady-duty Industry Equipment and Commercial Vehicles, Vienna. https://www.unido.org/sites/default/files/files/202004/MOR-140139_Eval\%20report_Vol_I_Training\%20Academy_2019.pdf

United Nations Industrial Development Organization. (UNIDO) (2020e). Index of industrial production. https://stat.unido.org/content/dataset_description/monthly-iip

World Economic Forum. (WEF) (2018). How governance is changing in the 4IR. Retrieved August 12, 2020, from https://www.weforum.org/agenda/2018/01/agile-governancechanging-4ir-public-private-emerging-technologies/

World Economic Forum. (WEF) (2019a). The Future of Jobs Report 2018. Geneva, Switzerland: WEF. http://www3.weforum.org/docs/WEF_Future_of_Jobs_2018.pdf

World Economic Forum. (WEF) (2019b). Strategies for the New Economy Skills as the Currency of the Labour Market. Geneva, Switzerland: WEF. http://www3.weforum.org/docs/ WEF_2019_Strategies_for the_New_Economy_Skills.pdf

World Economic Forum. (WEF) (2020). Jobs of Tomorrow Mapping Opportunity in the New Economy. Geneva, Switzerland: WEF. http://www3.weforum.org/docs/WEF_Jobs_of Tomorrow_2020.pdf

Yin, R. K. (2014). Case study research: Design and methods. Los Angeles, CA: Sage. 